\title{
Note on Translations, Transliterations, and Dates
}

All translations are mine, except where the source is given in the notes.

In transliterating Russian names, titles, and words, I have followed the Library of Congress system (System II as described in J. Thomas Shaw, The Transliteration of Modern Russian for English-Language Publications [Madison: University of Wisconsin Press, I967]), with the following modifications. Surnames are rendered with -sky rather than -skii (as in Dostoevsky). I have given the anglicized version of many Russian first names (e.g., Alexander, not Aleksandr, Peter rather than Petr), and retained well-known spellings of certain surnames (e.g., Tolstoy not Tolstoi, Gogol not Gogol'). I have also followed common practice in reproducing Russian surnames of foreign origin (e.g., Engelhardt, not Engel'gardt; Plehve rather than Pleve).

Except where explicitly stated to the contrary, all dates are given Old Style, that is, according to the Julian calendar in use in Russia until I9I8. To convert Old Style to our (Gregorian) calendar, add twelve days to nineteenth-century dates, thirteen to twentieth.

M. C. L. 

Russian Literary

Politics and the Pushkin

Celebration of I 880 
Literature is our Parliament too. Printing, which comes necessarily out of Writing, I say often, is equivalent to Democracy; invent Writing, Democracy is inevitable. ... The nation is governed by all that has tongue in the nation: Democracy is virtually there. Add only, that whatever power that exists will have itself, by and by, organized; working secretly under bandages, obscurations, obstructions, it will never rest until it get to work free unencumbered, visible to all. Democracy virtually extant will insist on becoming palpably extant.

- Thomas Carlyle, On Heroes, Hero-Worship, and the Heroic in History, I 840

Pushkin is an extraordinary phenomenon-perhaps a unique manifestation of the Russian spirit: he represents a stage to which Russians will have developed in perhaps two hundred years' time.

-Nikolai Gogol, "A Few Words about Pushkin," I 834

A new opinion about such a great phenomenon as Pushkin cannot suddenly arise out of nothing and appear ready-made; rather, it must have developed from the life of society itself, like everything that is alive; each new day, each new fact in life and in literature must also have changed our way of looking at Pushkin.

-Vissarion Belinsky, "The Works of Alexander Pushkin," I 843

$\mathrm{He}$ is dissolved in the air we breathe. He is in the bread we eat, the wine we drink. His verses are not really standing on our shelves. No, they are always with us, dissolved in our very blood.

-Alexander Kushner, 1987

It is not so much Pushkin, our national poet, as our relationship to Pushkin that has become our national characteristic.

-Andrei Bitov, Articles from a Novel, i 986 